\title{
ZNAČILNOSTI VODENJA V SLOVENSKIH OSNOVNIH ŠOLAH
}

\section{POVZETEK}

V današnjem času so ravnatelji slovenskih osnovnih šol razpeti med vlogo pedagoškega vodje in vlogo poslovodje zavoda. Izpolnjevati morajo tako zahteve, ki jim jih določa ustanovitelj (občina oz. država), ter želje in potrebe zaposlenih, ki jih vodijo. Na uspešnost dela ravnateljev zagotovo vplivajo značilnosti njihovega vodenja, te pa bi morale biti prilagojene karakternim značilnostim ravnateljev, zaposlenim, ki jih vodijo, pa tudi trenutni situaciji in okoliščinam šole, $v$ kateri delajo. Dobro poznavanje vseh teh dejavnikov bi ravnateljem in vsem, ki so vključeni v njihovo izobraževanje, omogočilo boljše usposabljanje za vodenje, kar bi posledično pozitivno vplivalo na uspešnost šol.

Ključne besede: menedžment v izobraževanju, stili vodenja, osnovna šola, ravnatelj, kvalitativna in kvantitativna metodologija

\section{LEADERSHIP AND MANAGEMENT STYLES IN SLOVENE ELEMENTARY SCHOOLS - ABSTRACT}

Today the principals of Slovene elementary schools are both educative leaders and managers of the institutions they head. They are torn between the founder's (community or state) demands and the needs of their employees. Their success depends on the style of their leadership, which should be adapted to their own character, the employees, the existing school conditions and its teachers. A clear understanding of all these factors would enable the principals and all parties involved in their education to provide management training that would positively influence the effectiveness of schools.

Keywords: management in education, leadership styles, elementary school, principal, qualitative and quantitative methodology

UDK: 37.091 .113

\section{UVOD}

Vodenje nepridobitnih organizacij, med katere sodi tudi šola, se zagotovo v marsičem razlikuje od vodenja podjetij. Nepridobitne organizacije so najpogosteje ustanovljene $\mathrm{z}$ namenom, da bi zagotavljale storitve, ki jih širša družba spozna za dragocene in jih profitno usmerjene organizacije ne morejo ali nočejo zagotavljati širši družbi (Možina, 2002).

Vodenje nepridobitne organizacije je specifično, saj naj bi bili v njej zaposleni ljudje z visokimi etičnimi in moralnimi načeli ter osebnostno močjo. Pri vodenju take vrste organizacije torej ne gre zgolj za vzdrževanje finančne in organizacijske stabilnosti, temveč za vzdrževanje ravnotežja med ponujenimi storitvami in preudarnim finančnim menedžmentom. Slednje velja tudi za vodenje vzgojno-izobraževalne organizacije.

Vodenje $\mathrm{v}$ teh organizacijah je zaupano ravnateljem, ki so hkrati pedagoški vodje in poslovodje zavoda, ki ga vodijo (izraz ravnatelj pri tem uporabljamo kot nevtralno obliko in se nanaša na moške in na ženske, torej ravnatelje in ravnateljice). To ustvarja funkcijsko sestavljanko pedagoško-andragoškega vodje za organiziranje, načrtovanje in delo z ljudmi skozi vodenje ter poslovodje za načrtovanje in izvajanje finančnega načrta, 
samokontrolo in kontrolo dogajanja na šoli ter doseženih rezultatov.

Zagotovo morajo ravnatelji svoj delovni čas in energijo ustrezno razporediti med poslovodni in vodstveni del. Kolikšen del svojega časa in energije pa sploh lahko namenijo vodenju svojih zaposlenih? Kakšno je njihovo vodenje? Koliko odločitev delegirajo svojim podrejenim? Koliko komunicirajo s svojimi pomočniki in koliko z zaposlenimi? Kako poteka ta komunikacija? Kako občutijo vodenje učitelji? Kako ravnatelji motivirajo svoje zaposlene? Kako uveljavljajo svojo moč? Kako usklajujejo različne interese med učitelji in ustanoviteljem? Kako se pogajajo? In, ne nazadnje, ali izpolnijo dano besedo?

Iskanje odgovorov na zastavljena vprašanja je vodilo do pričujoče raziskave, ki je bila opravljena na šestih osnovnih šolah v Sloveniji. Namen in cilji raziskave so bili: prepoznati značilnosti vodenja, ki se odražajo pri ravnateljih v slovenskih osnovnih šolah, odkriti njihovo lastno percepcijo vodenja, preučiti, kako vodenje ravnateljev zaznavajo njihovi zaposleni, analizirati, ali se značilnosti vodenja razlikujejo glede na spol vodje in velikost šole (število oddelkov), ki jo ravnatelji vodijo, ter na podlagi teoretičnih značilnosti razvrstiti prevladujoče stile vodenja ravnateljev slovenskih osnovnih šol glede na Herseyjevo in Blanchardovo teorijo situacijskega vodenja.

V nadaljevanju so najprej opisane značilnosti vodenja nepridobitnih organizacij, med katere sodi tudi šola kot vzgojno-izobraževalna organizacija, in značilnosti ravnatelja kot vodje vzgojno-izobraževalne organizacije. Nato so predstavljeni raziskava, njen potek in rezultati. V zaključku so podana priporočila za prakso in vodenje vzgojno-izobraževalne organizacije.

\section{VODENJE NEPRIDOBITNE ORGANIZACIJE}

Vodenje organizacije je proces, ki ima skupne značilnosti in lastnosti, a je zagotovo za vsako organizacijo specifičen in edinstven. Verjetno je definicij o vodenju ravno toliko, kolikor je knjig, napisanih o tem. Black in Porter namreč v svoji knjigi »Management: Meeting New Challenges« navajata znano Stogdillovo izjavo, da obstaja skoraj toliko opredelitev menedžmenta, kot je ljudi, ki so menedžment poskušali opredeliti (Black, Porter, 1999).

Splošne značilnosti vodenja, ki jih navajajo strokovnjaki v literaturi, veljajo tudi za vodenje nepridobitnih organizacij, med katere sodijo osnovne šole. Njihov namen sicer ni ustvarjanje dobička, temveč zagotavljanje storitev, ki jih družba potrebuje in so zanjo zelo dragocene. Pri vodenju take vrste organizacije torej ne gre zgolj za vzdrževanje finančne in organizacijske stabilnosti, temveč za vzdrževanje ravnotežja med kakovostjo ponujenih storitev in preudarnim finančnim menedžmentom.

Zagotovo se vodenje vzgojno-izobraževalne organizacije razlikuje od obvladovanja (menedžmenta) profitnih organizacij. Da bi laže razumeli koncept vodenja v vzgojno-izobraževalni organizaciji, moramo najprej spoznati samo organizacijo in način dela $v$ njej, ki je precej specifičen. Vzgojno-izobraževalna organizacija je institucija, v kateri potekata načrtno in sistematično izobraževanje ter načrtna in sistematična vzgoja (edukacija). Pri tem procesu ne gre samo za učenje, temveč tudi za prenos vnaprej določenih in izbranih vzorcev vedenja, znanj, delovnih spretnosti, vrednot in norm mlajšim generacijam, ki omogočajo ohranitev, reproduciranje in razvoj temeljnih družbenih institucij. Njen namen ni ustvarjanje dobička, temveč zagotavljanje storitev, ki jih družba potrebuje in so zanjo zelo dragocene. 
V vzgojno-izobraževalni organizaciji so zaposleni pedagoški delavci in drugi, ki nudijo organizaciji podporne dejavnosti, ki ne sodijo v sam vzgojno-izobraževalni proces. V vzgojno-izobraževalni organizaciji so tako zaposleni različni profili $\mathrm{z}$ različno stopnjo izobrazbe in različno dolgo delovno dobo. Povezujejo se v time, imenovane aktivi. Vodenje take organizacije je zelo specifično, saj naj bi bili v njej zaposleni ljudje $\mathrm{z}$ visokimi etičnimi in moralnimi načeli ter osebnostno močjo. Pri vodenju take vrste organizacije torej ne gre zgolj za vzdrževanje finančne in organizacijske stabilnosti, temveč za vzdrževanje ravnotežja med ponujenimi storitvami in preudarnim finančnim menedžmentom.

V literaturi iz 80. let prejšnjega stoletja, ko se je na pobudo strokovnjakov industrijskega menedžmenta začel uvajati menedžment v izobraževanju, se vodenje vzgojno-izobraževalne organizacije (ravnateljevanje) pogosto deli na menedžment in pedagoško vodenje, čeprav Bush trdi, da o tem ni splošno sprejete definicije, Grace pa piše o svojevrstnem paradoksu take delitve (Bush 2003, Grace 1995). Sam menedžment zajema način financiranja, zaposlovanje, marketinško usmerjenost, plačni sistem, številne predpise in normative. Ta vidik je teoretično veliko bolj obvladljiv in mu zato mnogi avtorji pa tudi ravnatelji kot vodje vzgojno-izobraževalnega zavoda posvečajo veliko več pozornosti in časa. Čeprav si mnogi ravnatelji želijo, da bi lahko več časa posvečali pedagoškemu vodenju, saj z njim gradijo in utrjujejo odnose z zaposlenimi, jih motivirajo, prispevajo h kvalitetnejšemu vzgojnoizobraževalnemu procesu, z njim ustvarjajo boljšo klimo $\mathrm{v}$ timu in sledijo viziji organizacije, jim ob vseh nalogah, ki jim jih nalaga menedžment, zanj včasih preprosto zmanjka časa. Pedagoško vodenje pa ni samo delo z ljudmi, je tudi zagotavljanje pogojev za izva- janje poučevanja in učenja ter uspešno načrtovanje, kamor sodi tudi načrtovanje razvoja zaposlenih (Hopkins, 2000).

Koren pravi, da ponekod še vedno obstaja predstava, da je namen menedžmenta $\mathrm{v}$ izobraževanju obvladovanje učiteljev in trženje oz. pridobivanje denarja od sponzorjev. $\mathrm{V}$ resnici vodenje ravnatelja v vzgojno-izobraževalni organizaciji ne ogroža učiteljeve profesionalnosti, temveč pomaga uveljavljati pedagoška znanja ter doseči temeljne cilje vzgoje in izobraževanja. Njegov namen je namreč optimalno izvajanje kurikula, povezovanje učiteljev, delo z ljudmi, sodelovanje s starši in okoljem, uresničevanje skupne vizije šole ter prepoznavanje šibkih in dobrih točk šole (Koren, 1999).

Dandanes v novejših besedilih o vodenju vzgojno-izobraževalnih organizacij ne najdemo več razlikovanja med menedžmentom in pedagoškim vodenjem. Uporablja se termin vodenje, ki je postal, kot pravi Bennett, ključni koncept, kadar govorimo o organizacijah in menedžmentu izobraževalnih organizacij in sistemov. Delitev torej ni več bistvenega pomena, fokus raziskovanja je preusmerjen na to, kako se vodenje kaže, kaj je uspešno vodenje in kdaj je v neki organizaciji najustreznejše (Bennett, Crawford in Cartwright, 2003).

\section{Ravnatelj kot vodja nepridobitne organizacije}

Po Mintzbergu naj bi imel glavni menedžer v nepridobitni organizaciji naslednje vloge: informacijsko (nadzornik, razširjevalec, govornik), medosebno (predstavnik, vodja, zveza) ter odločitveno (podjetnik, odpravljalec motenj, razporejevalec virov, pogajalec) (Možina in drugi, 2002).

Menedžerji nepridobitnih organizacij se posvečajo vodenju in poslovodenju svoje 
organizacije. Kot poslovodje skrbijo za čim učinkovitejše razporejanje javnih sredstev, kot vodje pa prevzemajo vodenje svojih zaposlenih s čim večjim nematerialnim motiviranjem, hkrati pa skrbijo za ohranjanje dobrih odnosov s skupnostjo, v kateri delujejo. Prav zaradi tako obširnega obsega dela in znanja zahteva vodenje nepridobitne organizacije visoko kvalificirane menedžerje, ki bodo tako dobri poslovodje kot vodje. $\mathrm{Ne}$ nazadnje so ključnega pomena tudi etične vrednote menedžerjev kot vodij, saj se ti primarno osredotočajo na vprašanja integritete, odprtosti, zanesljivosti, uslužnosti in dobrodelnosti nepridobitne organizacije.

Čeprav je bilo vodenje vzgojno-izobraževalnega zavoda sprva zgolj ravnateljeva domena, se danes pristojnosti in odgovornosti prenašajo tudi na druge zaposlene, ki jih $\mathrm{z}$ eno besedo poimenujmo vodstvo šole: direktor zavoda, ravnatelj, pomočnik ravnatelja, vodja enote oz. podružnice. Skupaj so odgovorni za določitev politike šole, ki mora biti usmerjena $\mathrm{v}$ čim boljšo kakovost ponujenih storitev.

Kolikšen del vodenja bo prenesel na preostalo vodstvo, je odvisno predvsem od posameznega ravnatelja šole. Nekateri gojijo avtokracijo oz. vodenje enega. Ravnatelj tu prevzame vse vodstvene naloge, deluje sam, sprejema odločitve, prevzame odgovornost in sprosti čas drugih pedagoških delavcev za poučevanje. Hkrati je preobremenjen s kupom drobnih administrativnih nalog in zato ne more več učinkovito voditi učiteljev, saj mora prevzeti polno skrb za več področij v organizaciji dela. Tako obstaja nevarnost, da avtokracija preide $\mathrm{v}$ diktatorstvo.

Drugi vidik kažejo šole, ki delujejo po načelu avtonomije. Ravnatelj delo porazdeli na manjše enote tako, da posamezniku ali sku- pini poveri, da opravi ali obvlada zaupano nalogo. V takem primeru mora ravnatelj že na začetku šolskega leta vso dejavnost šole enakomerno porazdeliti med učitelje. Če tako vsak prispeva svoj del, je koordinacija minimalna. Toda taka šola kot celota težko obvladuje vse pristojnosti in naloge, saj je preveč odvisna od posameznikov. Avtonomija se zato lahko sprevrže v anarhijo (Koren, 1999). Kakorkoli že si ravnatelj in vodstvo šole porazdelijo naloge, važno je, da ohranjajo avtonomijo šole in učiteljev, omogočijo šolsko programsko različnost, prisluhnejo željam učencev in staršev ter potrebam gospodarstva in okolice.

Ravnatelji morajo torej svoj delovni čas in energijo ustrezno razporediti med poslovodni in vodstveni del. Kolikšen del svojega časa in energije pa sploh lahko namenijo vodenju svojih zaposlenih? Kakšno je njihovo vodenje? Koliko odločitev delegirajo svojim podrejenim? Koliko komunicirajo s svojimi pomočniki in koliko z zaposlenimi? Kako poteka ta komunikacija? Kako občutijo vodenje učitelji? Kako ravnatelji motivirajo svoje zaposlene? Kako uveljavljajo svojo moč? Kako usklajujejo različne interese med učitelji in ustanoviteljem? Kako se pogajajo? In, ne nazadnje, ali izpolnijo dano besedo? Če želimo izvedeti, kakšne so značilnosti vodenja $\mathrm{v}$ slovenskih osnovnih šolah, moramo poiskati odgovore na vsa ta vprašanja.

\section{Predstavitev raziskave Značilnosti vodenja v slovenskih osnovnih šolah}

V slovenski literaturi o tej temi pišejo Koren v svojih knjigah »Ravnatelj med osamo in sodelovanjem « (1999) ter »Ravnateljevanje« (2007), Tavčar in Širca v 
»Management nepridobitnih organizacij « (1998), Tomićeva v »Menedžment v vzgoji in izobraževanju « (1995), Jelovac v »Jadranje po nemirnih vodah managementa nevladnih organizacij « (2001) idr. O značilnostih vodenja osnovnih šol lahko beremo tudi $\mathrm{v}$ člankih Krofliča z naslovom »Ravnateljeva avtonomija in pedagoško vodenje institucije« (2002), Primožiča »Ravnatelj raziskuje svoje delo« (2007), Resmana »Ravnatelj in vizija šole« (1994), Stančića »Kompetenčni profil idealnega ravnatelja « (2002) ter Velikonjeve »Vodenje v vzgoji in izobraževanju je del človeka« (1998).

Raziskava o vodenju v slovenskih osnovnih šolah, ki jo predstavljam v članku, temelji na študiji primera, v okviru katere je bila uporabljena kombinacija kvalitativnega in kvantitativnega pristopa $\mathrm{k}$ raziskovanju.

Cilji raziskave so bili:

1. spoznati različne stile vodenja in njihovo ustrezno rabo v različnih okoliščinah,

2. spoznati, katere značilnosti ravnateljevega vodenja se kažejo v slovenskih osnovnih šolah,

3. ugotoviti, ali se značilnosti vodenja razlikujejo glede na spol ravnateljev in velikost osnovnih šol,

4. preučiti, kako zaposleni občutijo vodenje ravnateljev,

5. na podlagi ugotovitev empiričnega dela raziskave prikazati stile vodenja ravnateljev po definicijah, ki sem jih iz literature povzela po različnih avtorjih. ${ }^{1}$

Rezultati raziskave naj bi ravnateljem izbranih osnovnih šol ponudili raziskovalno objektiven pogled na značilnosti njihovega vodenja. Da bi dobili vpogled v izbrano temo z več zornih kotov, so bili kot raziskovalna metoda uporabljeni polstrukturiran intervju z ravnatelji, anketa za zaposlene in opazo- vanje dela ravnateljev. Pridobljeni podatki iz raziskave so bili v nadaljevanju statistično analizirani. Rezultati raziskave so bili temelj za oblikovanje praktičnih priporočil ravnateljem in za sklepe raziskave.

\section{Potek raziskave}

Raziskava je potekala na šestih slovenskih osnovnih šolah. Vzorčenje je bilo neverjetnostno, saj je bil vzorec namenski, in sicer dve osnovni šoli z večjim (400 in več učencev), dve s srednjim (399 do 201 učenec) in dve z manjšim številom učencev (manj kot 200 učencev). V kvalitativni del raziskave so bili vključeni trije ravnatelji in tri ravnateljice, $s$ katerimi je bil opravljen intervju, $v$ kvantitativnem delu raziskave pa je bilo med zaposlene razdeljenih 150 anketnih vprašalnikov.

Terenski del raziskave je trajal šest tednov, vsak teden v eni izmed izbranih šol. V tem času so bili opravljeni opazovanje dela ravnateljev, intervjuji z njimi in anketiranje zaposlenih.

Opazovanje je potekalo strnjeno štiri dni zaporedoma na vsaki od izbranih šol. Delo ravnatelja je bilo spremljano skozi ves dan. $\mathrm{Ob}$ tem je potekalo beleženje pogostosti pojavov, predhodno določenih na check-listi. Pri opazovanju dela ravnateljev je bilo predvsem $v$ prvem in drugem dnevu opaziti, da je prisotnost opazovalca vplivala na komunikacijo in način dela ravnatelja. Čeprav so ravnatelji zagotavljali, da njihovo delo poteka večinoma na tak način, kot so ga izvajali v času opazovanja, so bile opazne razlike med načinom dela $\mathrm{v}$ prvih in $\mathrm{za}-$ dnjih dneh opazovanja.

Intervju $\mathrm{z}$ ravnateljem je bil na vrsti zadnji dan $\mathrm{v}$ tednu, po opravljenem opazovanju njegovega dela. Namen in cilji raziskave 
so bili ravnateljem sicer na kratko predstavljeni že v prošnji za opravljanje raziskave, nato je bil z njimi sklenjen dogovor o kraju, datumu in uri opravljanja intervjuja ter opazovanja njihovega dela na šoli. Pred vsakim intervjujem je bila ravnateljem zagotovljena anonimnost in uporaba podatkov zgolj v raziskovalne namene. Vsi intervjuji so bil opravljeni v pisarnah ravnateljev, vsi so dovolili snemanje in transkript posnetega intervjuja, ki jim je bil kasneje poslan v vpogled in odobritev.

V tem času so preostali zaposleni izpolnili anketni vprašalnik, ki je bil predhodno pilotno testiran na skupini desetih zaposlenih $\mathrm{v}$ šolstvu. Ker je pilotna študija pokazala, da so anketirancem navodila in vprašanja jasna, so bili na podlagi pilotne študije pripravljeni anketni vprašalniki. Na šolah, na katerih je bil opravljen intervju $\mathrm{z}$ ravnateljem, so bili izročeni pomočnikom ravnateljev, s katerimi je bil sklenjen dogovor, da jih bodo razdelili preostalim zaposlenim. Njim so zaposleni ankete tudi vrnili. $\mathrm{Na}$ vseh šestih šolah, kjer so bili opravljeni intervjuji, je bilo razdeljenih 150 anketnih vprašalnikov. Anketni vprašalnik je izpolnilo 117 zaposlenih, od tega 10 moških in 107 žensk. Šestinsedemdeset sodelujočih je bilo starejših od 30 let, 41 pa mlajših. Večina zaposlenih, ki so izpolnili anketo, je imela višjo izobrazbo (visoko šolo, univerzo, magisterij ali doktorat) - 98, 19 zaposlenih pa je imelo končano srednjo ali osnovno šolo. Anketiranih je bilo 89 učiteljev, šest svetovalnih delavcev in 22 drugih zaposlenih.

Po končani raziskavi so bili podatki, pridobljeni z intervjuji, prepisani, transkripti pa poslani ravnateljem $\mathrm{v}$ pregled in odobritev. Skupaj s podatki, pridobljenimi z anketami in opazovanjem, so bili nato analizirani in ovrednoteni.

\section{Rezultati raziskave}

Razpetost ravnateljev med demokratični in avtoritativni način vodenja

Ravnatelji osnovnih šol menijo, da njihovo vodenje pravzaprav temelji na sodelovanju z zaposlenimi, saj sebe vidijo kot prve med enakimi. Zavedajo se svojega poslanstva, kot pravi ravnatelj šole $\mathrm{C}$, »da moramo temeljna znanja, osnovna znanja, dati vsem učencem «, in skušajo delovati v dobro uporabnikom, zaposlenim in vsem, ki so kakorkoli vpeti v proces vzgoje in izobraževanja. Svoje vodenje vsi intervjuvani ravnatelji vidijo kot demokratično, saj »temelji na dogovarjanju z učitelji. Ti predstavijo svoje mnenje, potem pa se dogovorimo, kako bi to izpeljali, « opisuje ravnatelj šole B. S svojimi zaposlenimi se pogovarjajo, jih spremljajo, pridobivajo njihova mnenja in jih pri svojih odločitvah upoštevajo, saj, kot pravi ravnatelj šole A: »... sem prepričan, da lahko več dosežem $z$ dogovorom, sodelovanjem kot pa z ukazi in direktivami«. To poteka tako, da »na konferencah pozovem učitelje, vodje podružnic in ostale pedagoške delavce, da razmislijo o nečem, da pripravijo predloge za naslednjič, ko se sestanemo. Gre za povezovanje $z$ ostalimi, « pravi ravnateljica šole F. Svoja stališča so pripravljeni tudi spremeniti, ko »ugotovim, da so boljši argumenti. Si sicer vzamem čas za premislek, a lahko potem svoje stališče tudi spremenim, če me prepričajo $z$ boljšimi argumenti in rešitvami, « še dodaja ravnateljica šole E.

Večina pa jih meni, da »je potrebno iti včasih tudi na poti avtokratizma, odvisno od situacije«, pravi ravnateljica šole $\mathrm{D}$, saj »je ravnatelj razpet med to, kar mora narediti in je za to odgovoren, in če je nekaj nujno in obvezno in se to ne zgodi do določenega datuma, je potrebno dati demokracijo malo na stran in avtoritarno nastopit«. »Kar se pa mora izvršit, se pa mora, ne?! « pove 
ravnatelj šole $\mathrm{C}$. Tovrstne odločitve sprejmejo takrat, ko gre za »zahteve ministrstva (za šolstvo), pa tudi raznih razvojnih pedagoških inštitucij in tako naprej«.

Ravnatelj šole B je svoje razmišljanje o načinu vodenja strnil takole: »Ko govorimo o vodenju, sta tu po navadi dve opciji; demokratični in avtoritarni način vodenja. Tukaj mi velikokrat napačno razumemo, kaj je demokratično in kaj avtoritarno vodenje. Avtoritarno je vse predpisano, vse deklarirano, vse napisano, določeno vse do podrobnosti z vrha. Demokratično je pa tako, da rešitve iščemo skupaj, se odločimo za tisto, za katero mislimo, da je optimalna, ampak potem postane obvezujoča.« Ko je torej odločitev sprejeta, ne gre več za način vodenja, temveč za upoštevanje sprejetega. »Potem $p a$, ko je dogovor sprejet, podpisan, tu nastopi prava vloga demokratičnega vodje, da ne dovoli odstopanj. Ko je dogovor sprejet, je veljaven za vse. Samo pot sprejemanja
Ravnatelji osnovnih šol menijo, da njihovo vodenje temelji na sodelovanju z zaposlenimi. dogovora je pri avtoritarnem vodenju drugačna kot pri demokratičnem. Ko pa je nekaj sprejeto, je to obvezujoče in tu se ne da odstopati. Drugače ni mogoče doseči ciljev, « sklene svoje razmišljanje o različnih poteh sprejemanja odločitev.
Glede na podatke, pridobljene iz intervjujev, bi lahko sklepali, da ravnatelji svoj način vodenja najpogosteje zaznavajo kot sodelovanje z zaposlenimi. Pri takem stilu vodenja gre namreč po Herseyjevi in Blanchardovi teoriji situacijskega vodenja za spodbujanje razmišljanja pri zaposlenih, upoštevanje njihovih mnenj in predlogov, pri uresničevanju ciljev pa za upoštevanje njihovega predhodnega znanja, mnenj in idej. Na tak način gradijo odnos vzajemnosti in razvijajo zaupanje $\mathrm{v}$ sposobnosti zaposlenih (Hersey in Blanchard, 1988).
Večina ravnateljev pa se hkrati zaveda, da je treba občasno $\mathrm{v}$ nekaterih situacijah in pri nekaterih zaposlenih uporabiti direktivni, včasih mentorski, občasno pa tudi delegatski stil vodenja. Svoj stil vodenja tako največkrat prilagajajo posameznemu zaposlenemu. Ravnatelj šole A namreč pravi: »Saj vemo, da je vsak človek svoja zgodba, ne?! Ljudje smo zelo kompleksni, eni na isto stvar gledajo tako, drugi drugače in prav tako je na naši šoli. "Ravnatelj šole B prav tako razmišlja: »Več ljudi kot je skupaj, več je različnih videnj. Ljudje smo različni in samo taki, kot smo, smo pristni. Če je nekdo po naravi avtoritarno naravnan, potem kliče tudi po avtoritarnem vodenju. Če sem sam po naravi demokratičen vodja, ne morem v pretežnem delu uporabljati avtoritarnih vzvodov, saj bi tako izpadel neresno. Isto tako, če je nekdo avtoritaren in bo hotel nekaj po demokratični poti pripeljati do cilja, mu ne bo uspelo, ker $v$ osnovi postavlja stvari na avtoritaren način in bi ga potem, vmes, ljudje začeli malo po strani gledati. Enako velja za učitelje." $\mathrm{V}$ nasprotju z njimi pa ravnateljica šole D meni, da bi moral biti ravnatelj do vseh zaposlenih čim bolj enak, saj pravi: »Enak mora biti do vseh. Učitelji gledajo na to, ali si do fizika enak kot do anglista, ali si do razredne stopnje enak kot do predmetne. Izogibati se moraš ločevanja in ustvarjanja prepada med sodelavci. Gojiti moraš spoštovanje do njih kot do ljudi in kot do strokovnjakov, kajti oni so $v$ tej stroki doma. Tudi tisti, ki šele začenjajo delati, imajo določena znanja kot strokovnjaki in kot ljudje tudi.« Tako misli tudi ravnatelj šole B: »Praktično se skušam z vsemi pogovarjati kot z nekom, ki je za kolektiv zelo pomemben. Ne glede na to, kakšen poklic opravlja; najsi bo to učitelj, ali čistilka, ali kuharica, ali hišnik, ali pomočnica, ali svetovalna služba. Vsak ima svojo vlogo in vse vloge so pomembne. In tako jih jaz vidim in tako se z njimi pogovarjam.« 
Glede na podatke, pridobljene iz intervjujev, bi torej lahko sklepali, da so v izhodišču značilnosti vodenja ravnateljev slovenskih osnovnih šol podobne, se pa razlikujejo glede na osebnostne značilnosti ravnatelja, glede na zaposlene, ki jih ravnatelji vodijo, in situacijo oz. nalogo, ki jo morajo zaposleni v posameznem primeru opraviti.

Opaziti je bilo tudi razliko pri značilnostih vodenja ravnatelja šole $\mathrm{C}$ z manjšim številom oddelkov, kjer je šola vpeta $\mathrm{v}$ življenje vaške skupnosti: »Delujemo na vasi in tu moraš živeti v sožitju. Naša šola ni samo vzgojno-izobraževalna institucija, je hkrati kulturna ustanova, pa tudi športna. "V nasprotju s tem primerom pa ravnatelj šole A in ravnateljica šole $D$, ki vodita šolo $\mathrm{z}$ več oddelki v mestu, kjer deluje več osnovnih šol, občutita večji pritisk okolja, saj pravi ravnatelj šole A: »Naša šola je v dokaj specifičnem okolju, za razliko od ostalih osnovnih šol $v$ občini. Pa naj bo to s strani staršev, ki so zelo zahtevni. Poskusi vpletanja takšne in drugačne politike so na naši šoli izrazitejši kot na drugih šolah, «, ravnateljica šole D pa: »Ker so v tem kraju tri osnovne šole, lahko starši vpišejo svojega otroka kamorkoli. Zaposleni v našem kolektivu so obremenjeni s tem, kar je najbrž normalno.«

Večjih razlik med vodenjem ravnateljev in vodenjem ravnateljic, torej glede na spol, iz podatkov v intervjujih ni bilo zaznati. Skratka, značilnosti vodenja ravnateljev slovenskih osnovnih šol so v temelju zelo podobne, v detajlih pa zelo različne.

\section{Odnosi med ravnateljem in zaposlenimi}

Štirje od šestih intervjuvanih ravnateljev menijo, da najpogosteje sodelujejo, komunicirajo in največ nalog delegirajo svojim pomočnikom in svetovalni službi. Ravnatelj šole A pravi: »Vsakodnevno, in to večkrat na dan, komuniciram s svojima pomočnikoma in svetovalno službo. Ker v končni fazi, to so sodelavci, ki potem neposredno delajo z učitelji in učenci. « Prav tako meni ravnateljica šole D: »Najpogosteje komuniciram s pomočnico. Tudi učitelji zagotovo več komunicirajo z njo kot z mano, ker $v$ vsakdanjem življenju šole potrebujejo bistveno bolj njo kot mene. Veliko komuniciram tudi s svetovalno službo. "Ravnateljica šole F pri pogostosti komunikacije poleg pomočnice omenja tudi tajnico in računovodjo: »Recimo s pomočnico sva $v$ nenehnem kontaktu ... Ravno tako z računovodjo, pa tajnica je tudi zelo pomemben element. Tukaj smo stalno $v$ kontaktu. Ravnatelj šole C, kjer je manjše število oddelkov in zato ravnatelj nima sistematiziranega pomočnika, temveč je to funkcijo prevzela svetovalna delavka, pravi: $\gg N a$ centralni šoli pa je moja najbližja sodelavka oz. tista, ki mi pomaga, oz. prenesem nanjo tudi kakšne stvari, ki jih potem ona opravi, v bistvu naša svetovalna (delavka). Mislim, da posebej manjše šole, ki nimajo pomočnika, tam je svetovalna $v$ bistvu pomočnica. Čeprav je funkcija malo drugačna.«

Pričakovati je bilo, da bodo na šolah z manjšim številom oddelkov ravnatelji več komunicirali in sodelovali z učitelji, a se je skozi odgovore v intervjujih pokazalo, da to počneta ravnatelj in ravnateljica na šolah s srednje velikim številom oddelkov. Ravnatelj šole B pravi: »Moj način vodenja je tak, da sem pravzaprav povsod po malem zraven ... Čeprav sem povsod zraven, prepuščam iniciativo in pobude drugim, tistim, za katere se dogovorimo, da bodo vodili določeno stvar. Pregled pa imam. «Ravnateljica šole E pa: »Trudim se komunicirati $z$ vsemi, res pa je, da s sodelavci s podružnic malo redkeje $v$ direktni komunikaciji. Tukaj pa grem $v$ zbornico vsak dan najmanj dvakrat, da se pogovorim z njimi.«

Opazovanje in spremljanje dela ravnatelja, ki je potekalo na vsaki šoli štiri delovne dneve, 
je pokazalo, da ravnatelji v povprečju 29,6 odstotka svojih pogovorov dnevno opravijo s pomočniki, približno 52,1 odstotka komunikacije je namenjene učiteljem, preostalih 18,3 odstotka pa drugim zaposlenim. Verjetno bi moralo za večjo verodostojnost rezultatov opazovanje trajati dalj časa, tako pa je zaradi časovne omejitve raziskave vključevalo zgolj 24 delovnih dni. Pa vendar je mogoče iz pridobljenih rezultatov opazovanja sklepati, da ravnatelji $\mathrm{v}$ povprečju $\mathrm{z}$ učitelji komunicirajo več, kot si mislijo (pri tem gre za neposredno komunikacijo). Pred raziskavo sem pričakovala tudi manjši delež komunikacije med ravnatelji in preostalimi zaposlenimi, a je bil ta dejansko večji na račun komunikacije ravnateljev s tajnicami in računovodkinjami.

Večina komunikacije med ravnatelji in zaposlenimi je potekala ustno, nekaj prek elektronske pošte, obvestil na oglasni deski, po telefonu pa so ravnatelji večinoma komunicirali z vodji podružnic.

Kot so povedali tudi v intervjujih, veliko komunikacije med ravnatelji in zaposlenimi poteka v neformalni obliki. Večina jih tak način komunikacije uporablja, ker menijo, da je primernejši in z njim gradijo odnos z zaposlenimi. Ravnatelj šole A pravi: »Kolikor se da, je moj moto, da pogovor poteka $v$ neformalni komunikaciji. Kolikor se da. Formalno uporabim takrat, ko vidim, da je zid, da nekdo noče, pa bi moral zaradi narave dela. Takrat nastopim s formalno komunikacijo, drugače pa raje uporabim neformalno, kar se mi zdi edino pravilno in tudi rezultati so temu primerni. «Prav tako meni ravnatelj šole $\mathrm{C}$ : »Pridem v zbornico in se pogovarjamo. Se pošalimo, tako za dobro voljo. Lahko rečem, da je tega celo več, neformalnega. Ki pa lahko preide tudi v neko dobro zadevo, se lahko vmes že pogovorimo o določenih problemih, ne samo na sestankih. Veliko informacij pridobim prav $v$ takih pogovorih, ker če so formalni, je vse bolj zadržano. Neformalno pa lahko kako informacijo pokomentiraš čisto tako, ob kavici.«

Ravnateljica šole D z učitelji pogosteje komunicira formalno. $\mathrm{V}$ takem načinu vidi prednost, saj tako ohranja z vsemi približno enak odnos in objektivnejši pogled: » $Z$ uč $i$ telji komuniciram predvsem po uradni poti. Mi imamo postavljen strokovni svet, to so vodje aktivov, s katerimi se dobimo enkrat mesečno, pred pogovornimi urami. Potem imamo pedagoške konference, ki so po navadi enkrat mesečno, in vsakodnevna komunikacija med odmorom. Čeprav menim, da mora biti glavni odmor namenjen temu, da ga izkoristijo učitelji sami zase, ne pa da pride takrat $v$ zbornico ravnatelj in jih bombardira s tem, kaj vse je potrebno še narediti. Po treh urah pouka zagotovo učitelj potrebuje svoj mir, naj spije kavo v miru in se pogovori s kolegi. Obstaja nevarnost, da se začne ravnatelj vtikati v te pogovore in jim krati še tisti čas, ki ga imajo zase. Med nami poteka tudi neformalna komunikacija, a ta ni na neki prijateljski ravni, ker z nikomer od tukaj nisem nikoli učila $v$ aktivu, z nikomer od tukaj nisem hodila na ekskurzije, z nikomer od tukaj nisem bila v zvezi kolega. Ne prihajam iz tega kolektiva in nisem iz tega kraja doma. Zato imam z vsemi približno enak odnos. Ne vzvišen, ampak nekako na distanci. Omogoča pa mi nekako bolj realen pogled, in če gre za gradnjo odnosov med ljudmi, jih vsekakor lažje gradiš iz temeljev. Odnose, ki so že bili, a so bili na neki drugi ravni, je potem težko obrniti. Zamislite si, da sva bili midve do včeraj kolegici, potem pa pridem jaz sedet sem ... Midve sva do včeraj skupaj tolkli čez ravnateljico. Kaj bo zdaj? Midve bova morali zgraditi nov, drugačen odnos. Do včeraj sva se tikali, od danes naprej pa se bova vikali? Se bova vikali samo v šoli, in 
ko se bova videli $v$ trgovini, se bova tikali? Ne vem, če je potem to to.«

Med opazovanjem je bilo med ravnatelji in zaposlenimi zaznane več neformalne kot formalne komunikacije, še posebno na šolah z manjšim številom oddelkov. Mogoče bi bilo formalne oblike komunikacije več, če bi bilo opazovanje izvajano s popolnim opazovalcem, pri čemer se raziskovalec izogiba nepretrgani interakciji z zaposlenimi, ki jih proučuje, in če bi opazovanje trajalo dalj časa.

Opazovanje dela ravnateljev pa je pokazalo tudi, da pogostost komuniciranja ni sorazmerna s številom nalog, ki so delegirane zaposlenim. Delež pomočnikom delegiranih nalog je 38,3-odstoten, pri učiteljih je 42,9-odstoten, pri preostalih zaposlenih pa 18,8-odstoten. Tudi tukaj je verjetno smiselno opozoriti na to, da bi rezultati lahko bili drugačni, če bi opazovanje trajalo dalj časa.

Nabor nalog, ki jih ravnatelji delegirajo, je zelo raznolik. Že v intervjujih so povedali, da delegirajo večino nalog, bedijo nad izvedbo, strateške odločitve pa so $\mathrm{v}$ njihovi domeni, saj so konec koncev zanje odgovorni. Ravnatelj šole A na vprašanje, katere naloge delegira, odgovarja: »Vse tiste, ki jih lahko in ki jih tudi moram. Ker če bi hotel vse sam narediti, ne bi bilo od tega nič. Se pravi, vse tisto, kar je dnevno pomembno za dogajanje na šoli. Strateške odločitve pa seveda sprejemam sam. Večkrat sicer $v$ posvetovanju $z$ drugimi. Ampak zadnja beseda pa mora biti moja, saj v končni fazi sam kazensko in finančno odgovarjam za vse. Edini na šoli.« Podobno meni tudi ravnatelj šole $\mathrm{B}$ : »Razen letne ocene, ki jo naredim sam, in ostalih stvari, ki so v pristojnosti ravnatelja, kot na primer izrekanje vzgojnih ukrepov učencem, disciplinskih ukrepov ... Večina drugih stvari pa je dogovorjenih, za večino aktivnosti je že z letnim delovnim načrtom določen nek koordinator. « Ravnateljici šol D in E sodelavcem delegirata naloge, ki so jih opravljali že prej, za katere so strokovno usposobljeni in imajo z njimi predhodne izkušnje: »Tako da moji sodelavci opravljajo stvari, ki so jih že prej, jih obvladajo in vejo, kako tečejo $v$ tem upravnem delu ...«, »Odvisno od posamezne zadeve, njene kompleksnosti, obsežnosti, ne nazadnje pa tudi od direktne odgovornosti, ki jo imam ... V bistvu pri vsaki nalogi razmislim, kdo in kako mi je lahko $v$ podporo in pomoč, koliko mu zaupam ... Predvsem tiste, za katere vem, da so za njih usposobljeni in imam že izkušnje, da so jih dobro pripravili in da se bodo pri tem angažirali. Torej naloge, za katere res vem, da jih bodo dobro opravili ... to, za kar so strokovno usposobljeni.«

Po odgovorih ravnateljev $\mathrm{v}$ intervjujih bi lahko sklepali, da jih večina deluje po načelu avtonomije, kot jo utemeljuje Koren v knjigi »Ravnatelj med osamo in sodelovanjem«. Ravnatelj delo porazdeli na manjše enote in poveri posamezniku ali skupini, da opravi ali obvlada zaupano nalogo. V takem primeru mora ravnatelj že na začetku šolskega leta vso dejavnost šole enakomerno porazdeliti med učitelje. Če tako vsak prispeva svoj del, je potrebna minimalna koordinacija (Koren, 1999).

\section{Ravnateljevo uveljavljanje moči}

Čeprav ravnatelji veliko vlagajo $\mathrm{v}$ odnose $\mathrm{z}$ zaposlenimi in jim vzdrževanje dobre klime v kolektivu veliko pomeni, narava njihovega dela terja, da pri uveljavljanju nekaterih zahtev uporabijo moč vplivanja na sodelavce. Izbira ustrezne vrste moči pa je ena od odlik uspešnega vodje.

Po modelu Frencha in Ravena (French, 1999) ločimo pet vrst moči, ki pa jih lahko 
dopolnimo še z dvema vrstama moči po Coffeyju, Cooku in Hunsakerju (Coffey, 1994): legitimna moč, ki izhaja iz ravnateljevega položaja, moč nagrajevanja, ki izhaja iz možnosti ravnatelja, da zaposlene nagradi, moč pritiska, ki izvira iz bojazni zaposlenih pred kaznijo, referenčna moč, ki izhaja iz želje zaposlenih, da bili podobni ravnatelju, ker so jim všeč njegove osebnostne lastnosti, ekspertna moč, ki izvira iz ravnateljevega strokovnega znanja, informacijska moč, ki je povezana $z$ dostopom do informacij, in moč povezave, ki izhaja iz vpliva oz. odvisnosti ravnatelja in zaposlenih.

$\mathrm{V}$ intervjujih sem ravnatelje vprašala, kako uveljavljajo svojo moč in katero vrsto moči najpogosteje uporabijo pri uveljavljanju svojih odločitev. Večina je odgovorila, da ne želijo nastopati s pozicije moči, ampak vidijo rešitev v pogovoru in argumentih. Ravnatelj šole C pravi: »Poskušam utemeljiti ... Včasih jim svoje odločitve utemeljim tudi s svojim videnjem ... Kar se tiče mene kot ravnatelja, se poskušam z delavci pogovoriti. Če dobijo kakšna navodila, jim dam zraven še nasvet, naj naredijo po zdravi pameti. To je moj tak nasvet."Ravnatelj šole B poleg tega opozarja tudi na to, da je treba pogovor opraviti individualno in $\mathrm{z}$ osebo, ki se je zadeva dotika. Tako vedenje pričakuje tudi od zaposlenih: »Moč je v pogovoru. Predvsem v pogovarjanju in dogovarjanju ... Javno zelo malokdaj oziroma nikoli ne okregam zaposlenih. Če je potrebno opozoriti na napake, to naredim na individualnem pogovoru, pred kolektivom nikoli. Tudi sodelavce opozarjam, da stvari vedno razčistijo $v$ prisotnosti tistega, pri katerem se jim zdi, da vidijo napake. Povem jim tudi, da je to njihov pogled na problem, ne pa sodba.«

Večina ravnateljev ne želi uporabljati legitimne moči, saj se zavedajo, da imajo zapo- sleni enako izobrazbeno stopnjo kot sami. Raje uporabijo ekspertno moč. Ravnateljica šole D pravi: »Nikoli ne uporabljam moči $s$ pozicije ravnatelja zato, da bi rekla, da morajo zaposleni nekaj narediti zato, ker sem jaz tako rekla ali se tako odločila. Pozicija moči me pravzaprav ne zanima, da bi jo uporabljala zato, da bom uveljavljala svoje ideje ... V kolektivu, kjer so zaposleni na približno enakem izobrazbenem nivoju, govorim o strokovnih delavcih na šoli, tam se s takim načinom ne pride daleč, «, ravnatelj šole A pa: »Ne poslužujem se moči, ki izhaja iz mojega položaja, le v izjemnih primerih. Ta naj izhaja raje iz strokovne moči. « Podobno meni tudi ravnateljica šole $\mathrm{E}$ : »Največkrat stvari sodelavcem argumentiram. Legitimno moč redko uporabljam, bolj jih pohvalim, uporabim moč pohvale in spodbude, pozitivne ... Uporabljam tudi moč znanja, poznavanja dejstev, razmer. Včasih pa tudi, zato ker imam več informacij, informacijsko moč. «Ravnateljica šole F celo meni, da ji zaposleni pripisujejo večjo legitimno moč, kot jo želi sama: »Ja, jaz mislim, da mi drugi pripisujejo dosti večjo moč, ki izhaja iz položaja, kot jo želim sama občutiti. Jaz se nisem tega dela lotila zato, ker bi želela biti ravnateljica ali šefica ali kakorkoli že.«

Njihove trditve je potrdilo tudi opazovanje njihovega dela, ki je pokazalo, da pri uveljavljanju svojih odločitev v večini primerov resnično uporabljajo strokovno $(37,5$ odstotka) in referenčno moč (27,5 odstotka). Uporabe moči pritiska je bilo zelo malo (2,5 odstotka), uporabe negativne moči pa med opazovanjem ni bilo zaznati. So pa ravnatelji kljub zatrjevanju $\mathrm{v}$ intervjujih, da tega ne želijo početi, pri uveljavljanju svojih odločitev kar pogosto uporabljali tudi legitimno moč (19,2 odstotka) in moč nagrajevanja (13,3 odstotka). Glede na 
odgovore $\mathrm{v}$ intervjujih bi bilo pričakovati, da bo delež uporabe legitimne moči precej manjši. Mogoče je v realnosti celo še večji, saj je možno, da je bilo vedenje ravnateljev zaradi opazovalčeve prisotnosti drugačno, kot je sicer.

\section{Uspešnost šole ali/in dobra klima v kolektivu}

Eden od ciljev raziskave je bil tudi ugotoviti, ali se lastno videnje vodenja pri ravnateljih razlikuje od videnja pri zaposlenih. Na podlagi teoretičnih izhodišč študij Univerze Ohio State in Univerze Michigan, v katerih sta utemeljena dva načina vodenja, skrb za ljudi in skrb za naloge, so bila zaposlenim na osnovnih šolah $\mathrm{v}$ anketi zastavljena vprašanja, s pomočjo katerih je bilo ugotovljeno, ali zaposleni menijo, da so njihovi nadrejeni bolj usmerjeni v naloge ali v ljudi. Raziskovalci teh dveh univerz so namreč na podlag študij načina vodenja nadrejenih opredelili slednje kot usmerjenost $\mathrm{v}$ naloge oziroma usmerjenost v ljudi.

\section{Vidik ravnateljev}

Čeprav ravnatelj šole A na prvo mesto postavlja dobro klimo, saj pravi: »Najprej dobra klima, ker če ni dobre klime, šola ne bo uspešna, «, pa večina ravnateljev meni, da je oboje, uspešnost šole in klima, zelo pomembno, da pravzaprav eno vpliva na drugo oziroma da je eno pogojeno $\mathrm{z}$ drugim. Ravnatelj šole B meni, da je za dolgoročno uspešnost šole potrebno trajno vzdrževanje dobre klime: »Dobri rezultati so možni samo v dobri klimi ... Pozabiti na rezultate in samo klimo vzdrževati ..., potem je pa kolektiv sam sebi namen. Obešati se samo na rezultate in pozabiti na klimo ..., potem rezultati sicer so, a kratkotrajni. Torej ne eno ne drugo, ampak oboje skupaj.« Podobno meni ravnateljica šole D: »Oboje je pomembno; tako uspešnost šole kot dobra klima v kolektivu. To se ne more izključevati, saj če enega nimaš, tudi drugega po navadi ne. Zdaj, ali je lahko šola uspešna in ima slabo klimo? Mislim, da je meril za merjenje uspešnosti šole veliko in da nam mora biti danes vsem do tega, da šola dobro funkcionira in deluje. Dolgoročno. Sami moramo skrbeti za to, da delamo maksimalno dobro, in če bomo tako delali, bomo sigurno imeli rezultate."

Tudi ravnateljici šol E in F sta prepričani, da sta ta dva pojava med seboj tesno povezana in je v oboje treba vlagati dovolj časa in energije: »Če je dobra klima v kolektivu, vpliva na uspešnost. Gotovo pa ob nedoseganju ciljev in pogojni neuspešnosti tudi klima trpi. Tako da mislim, da je oboje zelo, zelo potrebno in pomembno in v oboje je potrebno vlagat. «In s tem začeti pri sebi: »Pravzaprav eno brez drugega ne gre ... In če je dobra klima, če pride človek vesel na delovno mesto, potem to tudi oddaja in je pripravljen več vlagat $v$ to in za to. Pravijo, da se to širi z vrha navzdol. Jaz si zato prizadevam, da bi vsak prišel ..., da bi vsak lahko svoj potencial izkoristil, da bi imel možnost pokazati to, kar zna, da bi imel možnost se uresničiti na delovnem mestu. In bodo potem tudi rezultati boljši. Ne morejo biti rezultati dobri, če ni dobre klime."

Večina ravnateljev torej meni, da so močno usmerjeni tako v uspešno opravljene naloge kot tudi v dobre odnose med zaposlenimi.

\section{Vidik zaposlenih}

Zaposleni so delo ravnateljev ocenili s pomočjo anketnega vprašalnika, $\mathrm{v}$ katerem so se postavljene trditve nanašale na usmerjenost ravnateljev $\mathrm{v}$ naloge in ljudi. Trditve od 1 do 12 so se nanašale na podlestvico usmerjenost $\mathrm{v}$ naloge, trditve od 13 do 22 pa na podlestvico usmerjenost $\mathrm{k}$ sodelavcem. 
Tabela 1: Splošno povprečje

\begin{tabular}{|l|c|c|c|c|c|}
\cline { 2 - 6 } \multicolumn{1}{c|}{} & $\mathrm{N}$ & Min & Max & M & SD \\
\hline $\begin{array}{l}\text { Usmerjenost } \\
\text { k nalogam }\end{array}$ & 115 & 1,00 & 4,58 & 2,2192 &, 96409 \\
\hline $\begin{array}{l}\text { Usmerjenost } \\
\text { k sodelavcem }\end{array}$ & 116 & 1,00 & 4,50 & 2,0123 &, 89321 \\
\hline
\end{tabular}

Tabela 1 prikazuje splošno povprečje na obeh podlestvicah. Za obdelavo podatkov je bil uporabljen računalniški programski paket SPSS, in sicer dvosmerni neodvisni t-test.

Glede na to, da je možni razpon odgovorov od 1 do 5, je iz rezultatov razvidno, da anketiranci ravnateljem ne pripisujejo niti izrazite usmerjenosti $\mathrm{k}$ nalogam niti $\mathrm{k}$ sodelavcem. Kljub temu je iz Tabele 1 razvidno, da anketiranci v povprečju dajejo nekoliko višje ocene na podlestvici usmerjenost $\mathrm{k}$ nalogam.

Zanimivo je bilo raziskati, ali se pri odgovorih pojavljajo razlike glede na spol zaposlenih. S pomočjo programa SPSS je bil opravljen neodvisni dvosmerni t-test. Rezultati so prikazani v Tabeli 2.

Tabela 2: Razlike glede na spol zaposlenih

\begin{tabular}{|c|c|c|c|c|c|c|c|}
\hline & Spol & $\mathrm{N}$ & $M$ & SD & $t$ & Df & $\begin{array}{l}\text { P (sig. } \\
\text { 2-tailed }\end{array}$ \\
\hline $\begin{array}{l}\text { Usmerjenost } \\
\text { k nalogam }\end{array}$ & $\begin{array}{l}\text { moški } \\
\text { ženske }\end{array}$ & $\begin{array}{r}10 \\
105\end{array}$ & $\begin{array}{l}1,9327 \\
2,2465\end{array}$ & $\begin{array}{l}96691 \\
, 96400\end{array}$ & ,984 & 113 & ,327 \\
\hline $\begin{array}{l}\text { Usmerjenost } \\
\text { k sodelavcem }\end{array}$ & $\begin{array}{l}\text { moški } \\
\text { ženske }\end{array}$ & $\begin{array}{r}10 \\
106\end{array}$ & $\begin{array}{l}1,5600 \\
2,0550\end{array}$ & $\begin{array}{l}36576 \\
, 91707\end{array}$ & $1,689^{-}$ & 114 & ,094 \\
\hline
\end{tabular}

Iz Tabele 2 je razvidno, da razlike med spoloma niso na ravni statistične pomembnosti. $\mathrm{Na}$ podlestvici usmerjenost $\mathrm{k}$ sodelavcem pa je videti, da se razlike $\mathrm{v}$ povprečnih odgovorih že približujejo ravni statistične pomembnosti. To morda kaže na to, da ženske ocenjujejo, da so ravnatelji bolj usmerjeni k nalogam, kot to vidijo zaposleni moškega spola.
Postavljena je bila domneva, da se bodo pokazale razlike tudi glede na starost zaposlenih. Ponovno je bil s pomočjo programa SPSS opravljen dvosmerni neodvisni t-test. Rezultati so prikazani v Tabeli 3 .

V Tabeli 3 lahko vidimo, da se razlike glede na starost udeležencev približujejo ravni statistične pomembnosti na podlestvici usmerjenost k nalogam. To kaže na to, da mlajši udeleženci v primerjavi s starejšimi pogosteje ocenjujejo, da so ravnatelji usmerjeni $\mathrm{k}$ nalogam. Razlike na podlestvici usmerjenost $\mathrm{k}$ sodelavcem med udeleženci glede na starost so minimalne in statistično nepomembne.

Nazadnje sem v raziskavi ugotavljala še, ali se pojavljajo razlike med videnjem vodenja ravnateljev tudi med zaposlenimi na različnih delovnih mestih. S pomočjo programa SPSS je bil opravljen enosmerni test ANOVA. Rezultati so predstavljeni v Tabeli 4 .

Iz Tabele 4 je razvidno, da imamo statistično pomembne razlike $\mathrm{v}$ odgovorih udeležencev na podlestvici usmerjenost $\mathrm{k}$ nalogam. Najvišje povprečne ocene so dajali svetovalni delavci, sledijo jim učitelji in nazadnje preostali zaposleni. To kaže na to, da svetovalni delavci bolj kot drugi zaposleni menijo, da so ravnatelji usmerjeni $\mathrm{k}$ nalogam. Na podlestvici usmerjenost $\mathrm{k}$ sodelavcem med odgovori udeležencev glede na mesto zaposlitve ne prihaja do statistično pomembnih razlik.

\section{Analiza rezultatov raziskave}

Rezultati raziskave so pokazali, da ravnatelji večinoma uporabljajo sodelovalni stil vodenja, da svoje vodenje vidijo kot zelo usmerjeno tako v naloge kot tudi v ljudi, da se vodenje šol z manj oddelki razlikuje od vodenja šol $z$ več oddelki, da pa ni večjih razlik glede na to, ali ima šola ravnatelja ali 
Tabela 3: Razlike glede na starost

\begin{tabular}{|c|c|c|c|c|c|c|c|}
\hline & Starost & $\mathrm{N}$ & M & SD & $t$ & Df & P (sig. 2-tailed \\
\hline $\begin{array}{l}\text { Usmerjenost } \mathrm{k} \\
\text { nalogam }\end{array}$ & $\begin{array}{l}\text { mlajši od } 30 \text { let } \\
\text { starejši od } 30 \text { let }\end{array}$ & $\begin{array}{l}41 \\
74\end{array}$ & $\begin{array}{l}2,4443 \\
2,0945\end{array}$ & $\begin{array}{l}, 99759 \\
, 92843\end{array}$ & 1,884 & 113 &, 062 \\
\hline $\begin{array}{l}\text { Usmerjenost } k \\
\text { sodelavcem }\end{array}$ & $\begin{array}{l}\text { mlajši od } 30 \text { let } \\
\text { starejšiod } 30 \text { let }\end{array}$ & $\begin{array}{l}41 \\
75\end{array}$ & $\begin{array}{l}2,1517 \\
1,9361\end{array}$ & $\begin{array}{l}, 92797 \\
, 87048\end{array}$ & 1,246 & 114 & ,215 \\
\hline
\end{tabular}

Tabela 4: Razlika glede na delovno mesto zaposlenih

\begin{tabular}{|c|c|c|c|c|c|c|c|}
\hline & Delovno mesto & $\mathrm{N}$ & M & SD & $\mathrm{df}$ & $\mathrm{F}$ & P (sig. 2-tailed \\
\hline $\begin{array}{l}\text { Usmerjenost } \mathrm{k} \\
\text { nalogam }\end{array}$ & $\begin{array}{l}\text { učiteli } \\
\text { svetovalni delavec } \\
\text { preostali zaposleni }\end{array}$ & $\begin{array}{r}87 \\
6 \\
22\end{array}$ & $\begin{array}{l}2,2869 \\
3,0278 \\
1,7311\end{array}$ & $\begin{array}{l}, 98404 \\
, 76497 \\
, 69671\end{array}$ & 114 & 5,556 & ,005 \\
\hline $\begin{array}{l}\text { Usmerjenost k } \\
\text { sodelavcem }\end{array}$ & $\begin{array}{l}\text { učiteli } \\
\text { svetovalni delavec } \\
\text { preostali zaposlen }\end{array}$ & $\begin{array}{r}88 \\
6 \\
22\end{array}$ & $\begin{array}{l}2,0331 \\
2,5833 \\
1,7736\end{array}$ & $\begin{array}{l}, 92352 \\
, 87502 \\
, 70615\end{array}$ & 115 & 2,073 & 131 \\
\hline
\end{tabular}

ravnateljico, torej glede na spol, ter da se videnje vodenja pri ravnateljih in zaposlenih precej razlikuje.

Glede na odgovore nekaterih ravnateljev v intervjujih bi lahko sklepali, da večinoma uporabljajo delegatski stil vodenja, pri katerem vodja relativno malo strukturira in spremlja dejavnosti v organizaciji, prav tako pa pri izbrani nalogi ne razvija odnosa z zaposlenimi, saj je ta praviloma že oblikovan in zgrajen, kar pa ne pomeni, da cilji in poti za doseganje ciljev niso jasni, temveč to, da vodja odgovornost za njihovo določanje in uresničevanje prenese na zaposlene, prepušča pa jim tudi odgovornost za izoblikovanje odnosov med njimi samimi; sodelovanje, prispevanje vsakega, upoštevanje predlogov idr. (Zabukovec, Boben, 2000).

Vendar pa so rezultati celotne raziskave, vključno z opazovanjem dela ravnateljev, pokazali, da po večini prevladuje sodelovalni stil vodenja. Pri takem stilu vodenja gre namreč po Herseyjevi in Blanchardovi teoriji situacijskega vodenja za spodbujanje razmišljanja pri zaposlenih, upoštevanje njihovih mnenj in predlogov, pri uresničevanju ciljev pa za upoštevanje njihovega predhodnega znanja, mnenja in idej. Tako vodje gradijo odnos vzajemnosti in razvijajo zaupanje v sposobnosti zaposlenih (Hersey in Blanchard, 1988).

Večina ravnateljev se hkrati zaveda, da je treba občasno $\mathrm{v}$ nekaterih situacijah in pri nekaterih zaposlenih uporabiti tudi druge stile vodenja. Direktivni stil vodenja občasno uporabljajo pri delu z novinci, ki še ne poznajo pravil, niso razvili svojih znanj in sposobnosti, nimajo delovnih izkušenj in še niso vzpostavili povezav znotraj in zunaj organizacije. Tak stil vodenja je po Herseyju in Blanchardu primeren tudi za vodenje sodelavcev, ki imajo nizko stopnjo interesa za delo, znanja in sposobnosti.

Poleg direktivnega stila vodenja včasih uporabijo tudi mentorskega, ki sledi direktivnemu, ko je novinec že nekaj časa 
zaposlen in še vedno potrebuje navodila za delo, a se postopoma že navaja na samostojnost. Primeren je tudi za vodenje bolj zainteresiranih sodelavcev, ki pa imajo še vedno nizko raven znanja in sposobnosti (povzeto po Gibson in drugi, 1994; Blanchard, Zigarmi, Zigarmi, 1985; Blanchard, Carew, Parisi-Carew, 1995; Hersey, 1997; Možina, 2002; Zabukovec, Boben, 2000).

Glede na podatke, pridobljene iz intervjujev, bi torej lahko sklepali, da so v izhodišču značilnosti vodenja ravnateljev slovenskih osnovnih šol podobne, se pa razlikujejo glede na osebnostne značilnosti ravnatelja, glede na zaposlene, ki jih ravnatelji vodijo, in glede na situacijo oz. nalogo, ki jo morajo zaposleni opraviti. Opaziti je bilo tudi razliko med značilnostmi vodenja ravnatelja šole z manjšim številom oddelkov, kjer je šola vpeta v življenje vaške skupnosti in je z njo zelo povezana, in značilnostmi vodenja ravnatelja in ravnateljice, ki vodita šoli $\mathrm{z}$ več oddelki v mestu, kjer deluje več osnovnih šol, saj občutita večji pritisk okolja. Večjih razlik med vodenjem ravnateljev in vodenjem ravnateljic, torej glede na spol, iz podatkov v intervjujih ni bilo zaznati. Skratka, značilnosti vodenja ravnateljev slovenskih osnovnih šol so v temelju zelo podobne, $\mathrm{v}$ detajlih pa zelo različne.

Namen in eden od ciljev raziskave je bil tudi preučiti, kako zaposleni občutijo vodenje ravnateljev in ali se njihov pogled razlikuje od pogleda ravnateljev. Glede na odgovore ravnateljev v intervjujih bi lahko sklepali, da so ti močno usmerjeni tako $\mathrm{v}$ naloge kot $\mathrm{v}$ ljudi, česar pa njihovi zaposleni, z razliko svetovalnih delavcev, ki bolj kot drugi zaposleni menijo, da so ravnatelji usmerjeni v naloge, ne dojemajo na enak način.

Rezultati ankete so namreč pokazali, da zaposleni ravnateljem ne pripisujejo niti izrazite usmerjenosti k nalogam niti izrazite usmerjenosti $\mathrm{k}$ ljudem. $\mathrm{V}$ povprečju so zaposleni dajali nekoliko višje ocene na podlestvici usmerjenost $\mathrm{k}$ nalogam. Ker se razlike glede na spol anketirancev $\mathrm{v}$ povprečnih odgovorih približujejo ravni statistične pomembnosti, nam to morda kaže, da ženske ocenjujejo, da so ravnatelji bolj usmerjeni k nalogam, kot to vidijo moški. Anketiranci, mlajši od 30 let, v primerjavi $\mathrm{z}$ anketiranci, starejšimi od 30 let, so pogosteje ocenjevali, da so ravnatelji usmerjeni k nalogam. Najvišje povprečne ocene so ravnateljem dajali svetovalni delavci, sledili so jim učitelji in nazadnje preostali zaposleni. To kaže na to, da svetovalni delavci bolj kot drugi zaposleni menijo, da so ravnatelji usmerjeni k nalogam.

Razloge za takšne rezultate bi bilo verjetno smiselno iskati prav $\mathrm{v}$ sorazmernosti intenzivnosti usmerjenosti $\mathrm{v}$ naloge in ljudi $\mathrm{s}$ časom, ki ga ravnatelji preživijo s posameznimi skupinami zaposlenih. Ne gre namreč zanemariti dejstva, da so večjo usmerjenost $\mathrm{v}$ naloge in ljudi ravnateljem pripisali prav svetovalni delavci, s katerimi ravnatelji preživijo največ časa, najmanjšo pa preostali delavci, s katerimi ravnatelji preživijo najmanj časa. Zagotovo imajo zato svetovalni delavci širši vpogled v obliko, način, zahtevnost in odgovornost dela ravnateljev.

Rezultati ankete zaposlenih torej kažejo na to, da zaposleni vodenja ravnateljev ne dojemajo tako, kot ga dojemajo sami ravnatelji, saj menijo, da ti niso pretirano usmerjeni niti v zaposlene niti v naloge. Povprečna ocena zaposlenih glede usmerjenosti ravnateljev $\mathrm{v}$ naloge je bila 2,22, v ljudi pa 2,01. Glede na model mrežnega vodenja, ki sta ga oblikovala Blake in Mouton, se tak način vodenja nagiba od vrste vodenja »na sredini poti« k vrsti vodenja »nemoč«. Če gre pri vrsti 
vodenja »na sredini poti« za vodenje, ki se zdi najboljše, saj omogoča uravnoteženost med potrebami zaposlenih in zahtevami organizacije, pa je vrsta vodenja »nemoč« najslabša izbira, saj se tak vodja izogiba odgovornostim, se boji ukazovati, ni aktiven, skratka, je neuspešen in nemočen (Možina, 2002, po Blake in Mouton, 1995).

Razlike v pogledu na vodenje pri samih ravnateljih in pri zaposlenih verjetno nastajajo zato, ker ravnatelji svojega vodenja ne zmorejo dovolj kritično presojati, kar je razumljivo, saj je vpliv subjektivne komponente ocene verjetno premočan. Po drugi strani pa zaposleni nimajo celovitega vpogleda $\mathrm{v}$ naloge in odgovornosti, ki jih obsega funkcija ravnatelja.

\section{Priporočila za prakso in vodenje vzgojno-izobraževalne organizacije}

Kljub razhajanjem v pogledih na vodenje pri ravnateljih in zaposlenih bi lahko trdili, da se ravnatelji dobro zavedajo odgovornosti, ki jo imajo tako do zaposlenih kot tudi do učencev in njihovih staršev, pa tudi do lokalne skupnosti, v kateri delujejo, ter ne nazadnje do ustanovitelja, države. Hkrati se zavedajo vloge, ki jo imajo v kolektivu. Zagotovo opravljanje takega dela, ki pomeni usklajevanje vseh zahtev, želja in potreb, zahteva velik psihični, včasih celo fizični napor. Zato jim

Ravnatelji slovenskih osnovnih šol so dobro seznanjeni s teorijami vodenja, poznajo ustrezne načine vodenja, uporabljajo pravilno komunikacijo in ustrezno vrsto moči, hkrati pa so zaradi pomanjkanja časa za zaposlene včasih premalo dostopni in premalo dosledni do njih. Čeprav sami menijo, da so močno usmerjeni v naloge in v ljudi, njihovi zaposleni te usmerjenosti ne čutijo tako močno. pogosto primanjkuje časa ali energije. Tudi sami zaznavajo, da je zaradi obremenjenosti z različnimi birokratskimi zadevami včasih zapostavljen odnos s sodelavci.

Ravnatelji naj si zato vzamejo čas za zaposlene, naj jim natančno razložijo pravila in postopke, ki naj jih zaposleni upoštevajo pri svojem delu, ter naj jim jasno povedo, kaj pričakujejo od njih. Namenijo naj jim ustrezno delo in naj spremljajo, kako ga opravljajo. Zaposlenim naj večkrat dajo povratno informacijo o kakovosti opravljene naloge, naj pohvalijo dobro in $\mathrm{z}$ različnimi vzvodi spodbudijo zaposlene, ki nalog ne opravijo dovolj dobro. Občasno naj jim predstavijo svoje delo in naloge, da bodo tudi tisti sodelavci, ki menijo, da so ravnatelji preveč usmerjeni $\mathrm{v}$ naloge in premalo v ljudi, spoznali, da je tako zaradi preobremenjenosti $\mathrm{z}$ delom.

Hkrati naj bodo dovzetni in naj spoštujejo mnenje zaposlenih, jim pomagajo, jih spodbujajo ter omogočijo njihov napredek in razvoj na osebnostnem in strokovnem področju. Za vse zaposlene naj veljajo enaka pravila, hkrati pa naj jih obravnavajo kot individuume in posledično prilagajajo stil vodenja. Predvsem pa naj bodo optimistični pri svojem delu in naj ne pozabijo na vrednote in moralne norme ter se zavedajo, da so zgled svojim sodelavcem.

\section{ZAKLJUČEK}

Zagotovo opravljanje dela ravnatelja pri vseh obveznostih, ki jih to vključuje, ni lahka niti zabavna naloga. A najverjetneje so se zanjo odločili ljudje, ki se dobro zavedajo odgovornosti in izzivov, ki jih prinaša ta funkcija. Tudi zato jo verjetno opravljajo z veseljem in navdušenjem. 
Zaupana jim je velika odgovornost za vodenje organizacije, ki naj bi izobraževala, predvsem pa vzgajala otroke, povezovala učitelje in druge delavce šole $\mathrm{v}$ trdne kolektive, $\mathrm{v}$ katerih bi s skupnimi močmi dosegali cilje in vizijo šole, ter vključevala starše, ki bi skupaj z učitelji našli skupno pot $\mathrm{v}$ iskanju najboljših rešitev za otroke. Vsak ravnatelj se na svoj način odloča, kako bo prišel do teh ciljev. Eden od namenov opravljene raziskave je bil tudi ta, da ravnatelji te načine ubesedijo in $\mathrm{s}$ tem mogoče začnejo samorefleksijo o načinu vodenja.

Predstavljena raziskava Značilnosti vodenja na slovenskih osnovnih šolah pa odpira tudi nove možnosti raziskovanja. Zagotovo bi bilo smiselno raziskati vzroke, zakaj se pogledi na vodenje pri ravnateljih in zaposlenih tako razhajajo. $\mathrm{S}$ tem se odpirajo nove možnosti raziskovanja, pa tudi nova vprašanja, odgovori nanje pa bi zagotovo zanimali tako ravnatelje kot druge zaposlene $\mathrm{v}$ šolah.

\section{LITERATURA}

Black, S., Porter, L.W. (1999). Management: meeting new challenges. New York: Prentice Hall.

Bush, T. (2003). Theories of Educational Management. London: Sage.

Coffey, R., Cook, C., Hunsaker, P. (1994). Management and Organizational Behaviour. Burr Ridge: Irwin.

French, J. R. P in drugi. (1999). The bases of social power. Journal of Applied Psychology, 73.

Gibson, J., in drugi (994). Organizations. Red Ridge: Irwin.

Grace, G. (1995). School Leadership: Beyond Education Management. London, Washington: The Falmer Press.

Hersey, P. (1997). The Situational Leader. Escondido: Center for Leadership Studies.

Hersey, P., Blanchard, K. (1998). Management of Organizational Behavior. New Jersey: Englewood Cliffs.
Hopkins, D. (2000). »Leadership and learning: Is there a link? «Managing Schools Today, September 2000: 39-43.

Jelovac, D. (2001). Jadranje po nemirnih vodah managementa nevladnih organizacij. Ljubljana: Zavod Radio Študent.

Kenneth, B., Crew, D., Parisi-Crew, E. (1995). Enominutni vodja oblikuje učinkovito delovno skupino. Ljubljana: Taxus.

Kenneth, B., Zigarmi, P., Zigarmi, D. (1985). Vodenje in enominutni vodja. Ljubljana: Taxus.

Koren, A. (1999). Ravnatelj med osamo in sodelovanjem. Ljubljana: Šola za ravnatelje.

Koren, A. (2007). Ravnateljevanje. Koper: Fakulteta za management.

Kroflič, R. (2002). Ravnateljeva avtonomija in pedagoško vodenje institucije. Sodobna pedagogika, 1: $66-77$.

Možina, S., in drugi (2002). Management, nova znanja za uspeh. Radovljica: Didakta.

Nigel, B., Crawford, M., Cartwright, M. (2003). »Introduction«. V Nigel, B., Crawford, M., Cartwright, M. (ur.), Effective Educational Leadership. London.

Primožič, M. (2007). »Ravnatelj raziskuje svoje delo«. Vodenje v vzgoji in izobraževanju, 1: 101-106.

Resman, M. (1994). »Ravnatelj in vizija šole«. Sodobna pedagogika, 3/4: 122-132.

Robbins, S. P. (2005). Organizational Behavior. New Jersey: Person Education International.

Staničić, S. (2002). »Kompetenčni profil idealnega ravnatelja (stališča in empirični rezultati)«. Sodobna pedagogika, 1: 168-182.

Tavčar, M. I., Trunk Širca, N. (1998). Management nepridobitnih organizacij. Koper: Visoka šola za management.

Tomić, A. (1995). Menedžment v vzgoji in izobraževanju. Ljubljana: Zavod Republike Slovenije za šolstvo.

Velikonja, M. (1998). »Vodenje v vzgoji in izobraževanju je del človeka«. Neprofitni management, 2/3: $13-15$

Zabukovec, V., Boben, D. (2000). Učitelji in stili vodenja. Ljubljana: Center za psihodiagnostična sredstva. 
1 Gibson in drugi; Blanchard, Zigarmi, Zigarmi; Blanchard, Carew in drugi; Možina; Zabukovec, Boben (Gibson in drugi, 1994; Blanchard, Zigarmi, Zigarmi, 1985; Blanchard in drugi, 1995; Hersey, 1997; Možina, 2002; Zabukovec, Boben, 2000). 